\title{
Instruments for Assessment of Mathematics Learning Outcomes of Fourth-Grade Elementary School Students
}

\author{
Ni Putu Mia Ari Yantini ${ }^{*}$, I Made Suarjana ${ }^{2}$, Made Sumantri ${ }^{3}$ \\ 1,2,3 Program Studi Pendidikan Guru Sekolah Dasar. Jurusan Pendidikan Dasar. Universitas Pendidikan Ganesha, Indonesia
}

\section{ART I CLE IN F O}

Article history:

Received March 08, 202

Revised March 11, 2021

Accepted April 30, 2021

Available online August 25, 2021

Kata Kunci:

Instrumen Penilaian, Hasil Belajar, Matematika

Keywords:

Assessment Instruments, Learning Outcomes, Mathematics

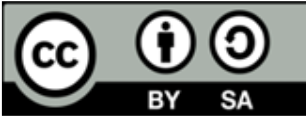

This is an open access article under the CC BY-SA license.

Copyright $(2021$ by Author. Published by Universitas Pendidikan Ganesha.

\begin{abstract}
A B S T RAK
Guru masih belum memperhatikan standar minimum yang dicapai oleh siswa, sehingga dalam pembuatan soal evaluasi kurang sesuai kemampuan siswa dan pencapaian kompetensi dasar dari materi pokok yang dipelajari. Penelitian ini bertujuan untuk menciptakan instrument penilaian hasil belajar matematika siswa kelas IV SD. Penelitian ini menggunakan penelitian pengembangan. Model yang digunakan pada penelitian ini yaitu menggunakan model ADDIE. Subjek yang digunakan adalah 2 ahli/pakar matematika dan 30 orang siswa sebagai responden. Teknik pengumpulan data yaitu observasi, wawancara, pencatatan dokumen, tes. Hasil penelitian dianalisis dengan validitas dan reliabilitas menunjukkan jumlah butir soal yang valid sebanyak 18 butir soal yang dinyatakan valid dan 2 butir soal yang tidak valid. Setelah itu dilakukan uji reabilitas menggunakan rumus Kuder Richardson 20 (KR-20) dengan bantuan aplikasi Microsoft Office Excel. Hasil perhitungan reliabilitas instrument diperoleh $r_{11}=0,82$ memiliki konsistensi yang "sangat tinggi". Maka, instrument penilaian hasil belajar matematika siswa kelas IV SD valid dan layak digunakan sebagai instrumen penilaian hasil belajar matematika. Implikasi penelitian ini yaitu instrument dapat dijadikan sebagai pedoman untuk mengembangkan instrument penilaian lainnya dan dapat membantu guru memahami cara pembuatan soal yang baik, sehingga tujuan pembelajaran dapat tercapai dengan optimal.
\end{abstract}

\begin{abstract}
A B S T R A C T
Teachers still do not pay attention to the minimum standards or basic competencies that must be achieved by students, so that in making assessment questions it is not according to students' abilities and the achievement of basic competencies from the subject matter being studied. This study aims to create an instrument for assessing mathematics learning outcomes for fourth grade elementary school students. This type of research is development research. The model used in this study is using the ADDIE model. The subjects used were 2 mathematicians/experts and 30 students as respondents. Data collection techniques are observation, interviews, document recording, tests. The results of the study were analyzed with validity and reliability showing the number of valid items as many as 18 items that were declared valid and 2 items that were not valid. After that, the reliability test was carried out using the Kuder Richardson 20 (KR-20) formula with the help of the Microsoft Office Excel application. The results of the calculation of instrument reliability obtained $r 11=0.82$ has a "very high" consistency. Thus, the instrument for assessing mathematics learning outcomes for fourth grade elementary school students is valid and appropriate to be used as an instrument for assessing mathematics learning outcomes. The implication of this research is that the instrument can be used as a guide for developing other assessment instruments and can help teachers understand how to make good questions, so that learning objectives can be achieved optimally.
\end{abstract}

\section{INTRODUCTION}

Learning is delivering information or knowledge to students (Dwipayana et al., 2018; Sari et al., 2016). The learning process is said to be successful if all students take an active role in learning (Abdul Karim et al., 2020; Soekisno, 2015). Learning becomes effective if the teacher can create a conducive 
learning environment. Teachers must create effective learning in all subjects, including mathematics learning (Crismono, 2017; Febriana et al., 2020). Mathematics learning is a mathematical connection ability that means connecting mathematics learning accompanied by solutions such as linking between topics, linking between concepts with daily life applications (Bayles et al., 2021; Davidi et al., 2021; Nugraheni, 2013). Mathematics learning aims to develop cognitive aspects and affective aspects in which life values are contained (Bosica et al., 2021; Miranda et al., 2021). One example of learning mathematics is inseparable from students' daily lives, such as fractions, when students divide objects into smaller parts (Ardhiyah \& Radia, 2020; Indriani, 2018; Trisnawati \& Suharno, S dan Kamsiyati, 2019).

In general, the teacher acts as an evaluator of student learning, which means assessing student learning. By assessing the students, the teacher will get feedback about the implementation of educational interactions that have been carried out, whether or not it is appropriate and appropriate or not the implementation of similar learning continues (Durán et al., 2019; Jannah et al., 2021; Kirom, 2017). A good assessment has principles such as being objective, integrated, economical, transparent, accountable, and educative (Sari \& Setiawan, 2020; Subagia \& Wiratma, 2016). Assessment activities are usually carried out at the end of learning, with teacher assessment activities to determine the extent to which students understand the material presented in the learning process (Febriyanti \& Jayanta, 2018; Gaol et al., 2017). Quality education reflects a credible and quality assessment. For this reason, teachers are required to provide a comprehensive and comprehensive assessment of the achievement of student competencies (Dessiane \& Kristin, 2021; Kim \& Sihyun Park, 2021; Setiawan, 2017). Credible and quality assessments influence the expected results (Friantary \& Martina, 2018; Maqableh \& Alia, 2021; Wicaksono et al., 2020). The assessment does not only look at the results, but the assessment looks at the overall planning, implementation, and reporting (Pantiwati, 2016).

However, in reality, many teachers have difficulty making student learning assessment instruments (Ariani, 2020; Arif, 2016; Wulandari et al., 2019). In addition, the low student learning outcomes are caused by the lack of suitability of the learning outcomes instruments with the level of students' abilities (Maghfiroh \& Hardini, 2021; Sari et al., 2019). This problem is also experienced by elementary schools in the Lompa Batang cluster. Based on interviews with several elementary school teachers in the Lompa Batang Gugus, it was found that there were several obstacles in the assessment of mathematics learning such as the assessment instruments used by classroom teachers, basic competencies and assessment indicators with questions that needed to be sorted and readjusted. Teachers still do not pay attention to minimum standards or basic competencies, learning objectives that students must achieve. The teacher still makes assessment questions in certain materials or accordance with students' abilities regardless of whether the student has achieved the essential competencies of the subject matter being studied. In addition, there is a lack of validity and reliability of a tested assessment instrument. Student learning outcomes in mathematics content are still low. Teachers do not have a clear assessment instrument grid, which is the initial foundation for adjusting the competencies to be measured in making the related assessment instruments. It is important to note because it will impact the assessment of student learning outcomes that are less than optimal and accurate. Each student needs to get an evaluation that can test the extent of their understanding of a particular material topic. So, if the teacher still uses an assessment instrument whose validity and reliability are not tested, it will impact student learning outcomes that are less precise.

One solution that can be done is to develop an assessment instrument. Assessment is an activity to measure the achievement of student learning outcomes (Wicaksono et al., 2016; Zuliani et al., 2017). Measurement of student learning achievement includes cognitive, affective, and psychomotor assessments (Asghar et al., 2018; Lwande et al., 2021). Specifically, the cognitive domain is divided into two dimensions of cognitive processes and the dimensions of knowledge. The cognitive process dimension contains six categories of Bloom's Taxonomy, namely remembering (C1), understanding (C2), applying (C3), analyzing (C4), evaluating (C5), and creating (C6). Meanwhile, the knowledge dimension contains four categories, namely factual knowledge (K1), conceptual knowledge (K2), procedural knowledge (K3), and metacognitive knowledge (K4) (Gunawan \& Palupi, 2012; Netriwati, 2018; Widodo, 2020). This mathematics learning outcome instrument can assist teachers in measuring students' abilities and understanding, especially fractional material. The instrument developed is by the demands of essential competencies and indicators developed on fractional material. This instrument can measure students according to competency standards and appropriate assessment indicators and can make learning outcomes better so that this will have an impact on both students and teachers.

Previous research stated that the developed mathematics learning outcome assessment instrument was suitable for assessing students (Faidah et al., 2019; Ndiung \& Jediut, 2020). Another finding states that HOTS-based questions are essential to measuring learning achievement (Prastikawati et al., 2021; Umami et al., 2021). Quality assessments influence the expected results (Friantary \& Martina, 
2018; Wicaksono et al., 2020). The difference in previous research is that the instrument measures students' high-level abilities and uses strategies. Meanwhile, the development of this instrument focuses more on measuring students' abilities in achieving essential competencies and indicators, especially on fractional material. There has been no development related to learning outcomes instruments in Class IV Elementary School Cluster Lompa Batang, Melaya District, based on previous research. This study aims to create an instrument for assessing mathematics learning outcomes in the fraction material of fourth-grade students at the Lompa Batang Elementary School, Melaya District. The existence of this written instrument is expected to improve students' thinking skills and student learning outcomes.

\section{METHOD}

This type of research is Research and Development, which is research used to develop a particular product and test its effectiveness. This development research was designed using the ADDIE model (analyze), (design), (development), (implementation), and (evaluation) (Wulandari et al., 2020). In connection with the current covid-19 pandemic, the implementation and evaluation stages cannot be carried out due to conditions that are not yet possible. The analysis phase is carried out by seeking information related to student needs and analyzing learning topics. The planning stage is the design of the fourth-grade elementary school mathematics content assessment instrument. The development stage is the embodiment of the previous design stage. At the design stage, a grid of approved assessment instruments has been prepared to proceed to make items. The implementation stage is to implement the assessment instrument developed, which has gone through trials and has been declared relevant, valid and reliable, so it is feasible to test the learning outcomes of the ADDIE model presented in the form of an image as shown in Figure 1.

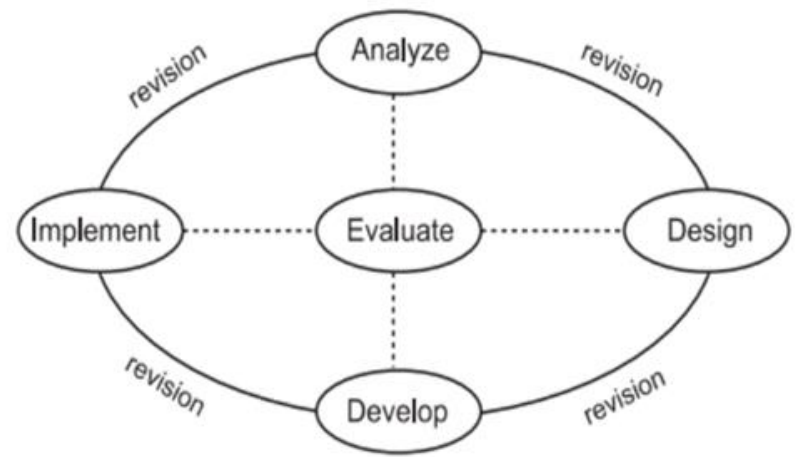

Figure 1. ADDIE Development Model (Wulandari et al., 2020)

Research on the development of an instrument for assessing Mathematics learning outcomes on the Fractional Material of Class IV Students at the Lompa Batang Elementary School, Melaya District, will be submitted to experts in the field of Mathematics. The subjects used were two mathematicians and 30 students as a test. The data collection method is the method that will be used in this development research. Several types of data collection methods are used in this study, namely, observation, interviews, document studies, and tests. In this development research, the instrument used is an assessment instrument in the form of a test. The type of test used is an objective test in the form of multiple choice. Multiple choice is a test in which each item provides several alternative answers or answer choices, one of which is the correct answer, while the incorrect option is a distractor. Multiple-choice tests are arranged according to the number of essential competencies and indicators found in fourth-grade mathematics learning in the odd semester. There will be four options or four alternative answers in the multiple-choice test, namely (a, b, c, and d), which are alternative answers. The data analysis method is the method that will be used to find out the description of whether or not the assessment instrument is used as an evaluation tool. An instrument can be said to be suitable by knowing the validity and reliability instrument. Based on that in this development, research through test validity and test reliability. The validity test that will be used in this development research is the Gregory formula. The assessment instrument used was multiple choice and in the form of a 0 and 1 value dichotomy. The validity test of the selected items was the biserial correlation technique. The reliability of a test or a measuring instrument is said to be reliable if the test is consistent. To calculate the instrument's reliability value, the formula used is Kuder Richardson 20 (KR-20). In measuring the reliability of a test using the table of criteria presented in Table 1. 
Tabel 1. Kriteria Reliabilitas Instrumen

\begin{tabular}{cc}
\hline Test Reliability & Criteria \\
\hline $0.0-0.19$ & Very low \\
$0.20-0.39$ & Low \\
$0.40-0.59$ & Currently \\
$0.60-0.79$ & Tall \\
$0,80-1.00$ & Very high \\
\hline
\end{tabular}

\section{RESULT AND DISCUSSION}

\section{Result}

This research development process uses the ADDIE model, which is a research model consisting of several stages. The ADDIE model is a model that seeks to solve learning problems and student characteristics because it is programmed and systematic. This model consists of five stages, including analysis (analysis), design (planning), development (development), implementation (implementation), and evaluation (evaluation). In this development, the stages carried out are only up to the development stage because of the current situation and conditions, namely the Covid-19 pandemic, so the implementation and evaluation stages cannot be carried out. This development chose the ADDIE model because the model has a systematic and programmed sequence and considers the needs and characteristics to produce an appropriate instrument for students. The first stage is analysis (analysis) by analyzing needs and topics. The analysis of needs in question refers to teachers and students to find out the mathematical assessment instruments needed for evaluation tools for students in learning mathematics outcomes by teachers at the Lompa Batang Elementary School, Melaya District, through observation and interviews with several teachers. The needs analysis found that it was necessary to develop a valid and appropriate instrument for assessing mathematics learning outcomes, especially in the fractional material at the Lompa Batang Gugu's Elementary School, Melaya District. Learning topics are meant to analyze core competencies, essential competencies, indicators, and learning objectives through teacher books toto design relevant assessment instruments. The results of the topic analysis show that it is necessary to adjust the assessment indicators with essential competencies to produce instruments that can test students according to the exemplary standards.

Table 2. Grid of Assessment Instruments

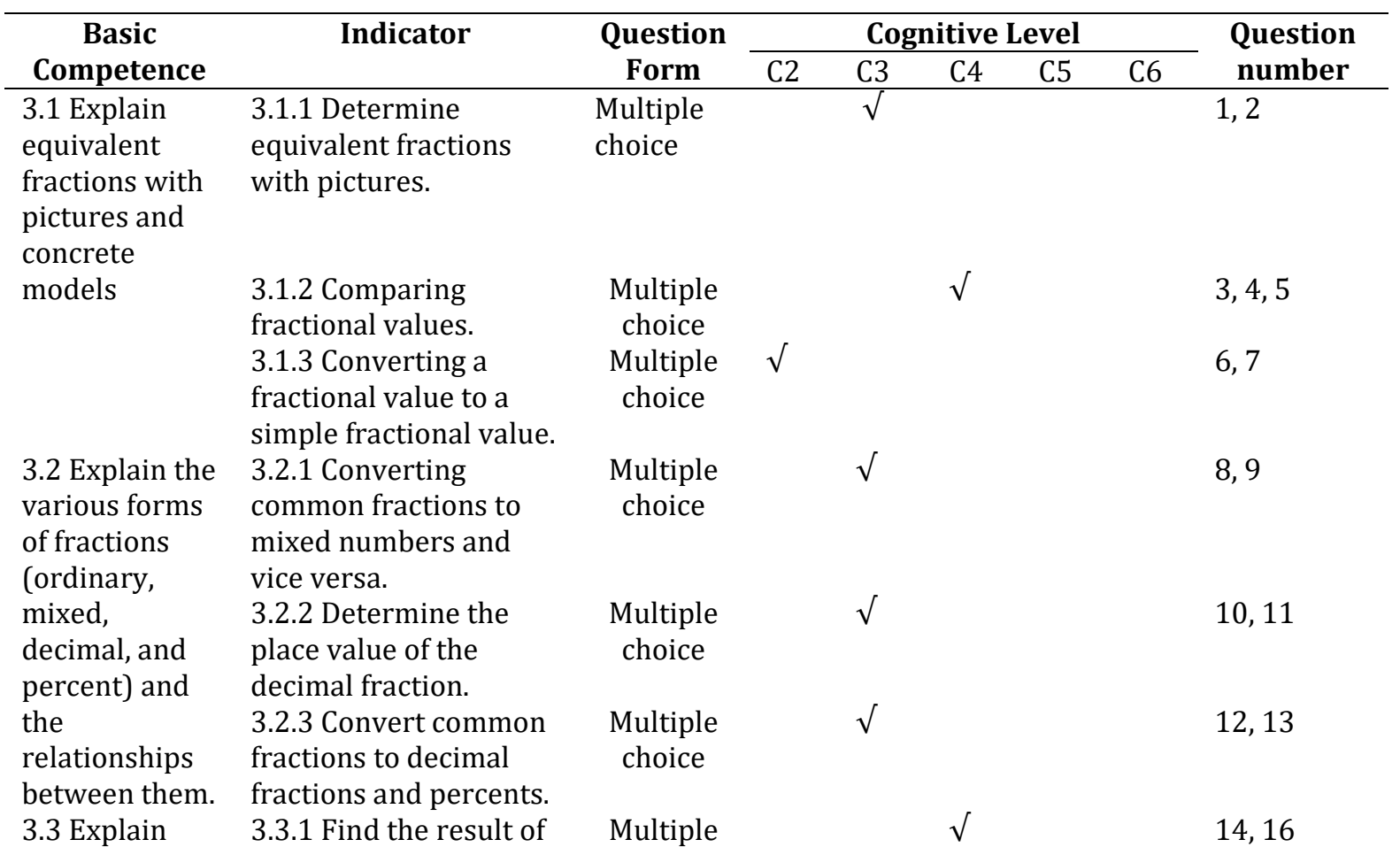




\begin{tabular}{|c|c|c|c|c|c|c|c|c|}
\hline \multirow{2}{*}{$\begin{array}{c}\text { Basic } \\
\text { Competence }\end{array}$} & \multirow[t]{2}{*}{ Indicator } & \multirow{2}{*}{$\begin{array}{c}\text { Question } \\
\text { Form } \\
\end{array}$} & \multicolumn{5}{|c|}{ Cognitive Level } & \multirow{2}{*}{$\begin{array}{c}\text { Question } \\
\text { number }\end{array}$} \\
\hline & & & $\mathrm{C} 2$ & C3 & $\mathrm{C} 4$ & $\mathrm{C} 5$ & $\mathrm{C} 6$ & \\
\hline $\begin{array}{l}\text { and perform } \\
\text { estimations of } \\
\text { the number, } \\
\text { difference, } \\
\text { product, and } \\
\text { quotient of } \\
\text { two whole }\end{array}$ & $\begin{array}{l}\text { adding and subtracting } \\
\text { the same denominator } \\
\text { as the picture. } \\
\text { 3.3.2 Find the results of } \\
\text { adding and subtracting } \\
\text { fractions with different } \\
\text { denominators. }\end{array}$ & $\begin{array}{l}\text { Multiple } \\
\text { choice }\end{array}$ & & & $\sqrt{ }$ & & & 15,18 \\
\hline $\begin{array}{l}\text { numbers as } \\
\text { well as } \\
\text { fractions and }\end{array}$ & $\begin{array}{l}\text { 3.3.3 Find the result of } \\
\text { adding and subtracting } \\
\text { mixed numbers. }\end{array}$ & $\begin{array}{l}\text { Multiple } \\
\text { choice }\end{array}$ & & & $\sqrt{ }$ & & & 17 \\
\hline decimals. & $\begin{array}{l}\text { 3.3.4 Solving fractional } \\
\text { number problems } \\
\text { through activities that } \\
\text { occur in everyday life. }\end{array}$ & $\begin{array}{l}\text { Multiple } \\
\text { choice }\end{array}$ & & & $\sqrt{ }$ & & & 19,20 \\
\hline
\end{tabular}

The development stage is carried out by making instruments according to the planned grid. It begins with the creation of each item that has been adjusted to the predetermined assessment indicators. The assessment instrument is each item based on cognitive level based on Bloom's Taxonomy. The assessment instrument that has been prepared has gone through revision based on input from the supervisor and has been continued with expert tests in mathematics. The expert test is carried out with two experts in the field of mathematics to get data for each item that is declared relevant or not in terms of content or material. Instruments that have gone through expert testing are re-tested with students at the Lompa Batang Gugus's Elementary School, Melaya District, and get the data is used to determine whether the items are valid. The assessment instrument in this study was tested with two expert judges to determine the validity of the content. Based on the content validity test data conducted by experts/judges, the results are shown in Table 3.

Table 3. Expert Test Results

\begin{tabular}{|c|c|c|c|}
\hline \multicolumn{2}{|c|}{ Expert I } & \multicolumn{2}{|c|}{ Expert II } \\
\hline Relevance & Irrelevant & Relevance & Irrelevant \\
\hline $\begin{array}{l}1,2,3,4,5,6,7,8,9,10,11,12,13,14,15 \text {, } \\
16,17,18,19,20 .\end{array}$ & - & $\begin{array}{l}1,2,4,5,6,7,8,9,10,11,13 \\
14,15,16,17,18,19,20 .\end{array}$ & \\
\hline
\end{tabular}

Based on the calculation of the content validity of the Mathematics learning outcome assessment instrument, the result is 1.00 . Then the content validity results show that the number 1.00 is converted into a table of content validity criteria providing information that the content validity of the mathematics learning outcomes assessment instrument is "very high." Furthermore, the validity of the items was tested. The data used were obtained when the instrument was tested with fourth-grade students of the Lompa Batang Group. The instrument trial process was carried out with a small group test due to the pandemic situation and conditions that required students to attend school with $50 \%$ of the total number of students in each class with social distancing. So that in testing the questions carried out by small group tests in each school. The data obtained were analyzed by using a biserial correlation formula and in the calculation using Microsoft Excel. Based on the test instrument with a small group test with a total of 30 students or 30 respondents and using a significant level of $5 \%$, namely rtable $=0.361$. Each correct item must have rcount > rtable. If rcount < rtable, the item cannot be declared valid. So based on the analysis of the data obtained, 18 items were declared valid, and two were invalid, namely in questions numbers 7 and 13. The reliability test of an instrument was carried out when the instrument was valid. So that in this case, the number of items used is 18 items because the item validity test shows 18 valuable items. In calculating the instrument's reliability using the biserial points of the Kuder Richardson (KR20) formula using the Microsoft Excel application in the calculation. Based on the calculations carried out, from 18 valuable items or $n=18$, it was obtained that the instrument's reliability, $r 11=0.82$. It was then converted to determine the level of reliability on the instrument with the Test Reliability Criteria. So it can be concluded that the level of reliability of this assessment instrument has a "very high" consistency.

\section{Discussion}


Based on the results of data analysis, it can be concluded that the assessment instrument is valid and feasible to be used as an assessment instrument for students - several factors, namely as follows, cause instruments that are valid and appropriate to use. First, the instrument that assesses mathematics learning outcomes is valid and feasible because it has met the requirements of a good assessment instrument. A good instrument is if it has passed the correct instrument procedure (Gaol et al., 2017; Pentury et al., 2019). The instrument developed has been through validity and reliability tests (Monica et al., 2011; Schlimbach \& Asghari, 2020). In addition, this instrument has been revised according to suggestions and input from experts so that the assessment instrument developed is better.

Second, the assessment instrument can be used to obtain information and develop thinking skills on fractional material. An instrument is a measuring tool that can be used to assess something in collecting data to obtain the desired information (Anwar et al., 2020; Gaol et al., 2017; Srirahayu \& Arty, 2018). The existence of an instrument aims to determine the achievement of student understanding (Adjii, 2019; Yusup, 2018). Each test item must be arranged according to the learning objectives and level of student competence (Chan \& Ismail, 2014; Segers et al., 2018). The instrument development research has very high validity and reliability criteria. Based on the results obtained, the learning outcomes instruments have validity and reliability, in very high criteria. So that this instrument can be used as an evaluation tool or an accurate learning assessment on the cognitive aspects of mathematics learning outcomes, especially the fraction material.

The findings of previous research stated that the assessment instrument was valid and reliable, feasible to use, and could measure students' abilities (Arif, 2016; Solihah et al., 2020; Yusup, 2018). Other findings also state that assessment instruments can measure students' understanding (Ndiung \& Jediut, 2020; Utami \& Wardani, 2020). Another finding states that test questions are essential to measure learning achievement (Prastikawati et al., 2021; Umami et al., 2021). So, it can be said that the instrument for assessing learning outcomes in grade IV elementary school mathematics is valid and can be used to measure students' abilities. The advantage of this research is that the instrument created has been validated and developed with the ADDIE model, so it is feasible to use. However, this research also has limitations: it cannot be carried out until the implementation stage, besides that instrument trials are only carried out on a small number of students. This research contributes to teachers making good learning outcomes instruments. This research implies that the instrument can be used as a guide for developing other assessment instruments and help teachers understand how to make good questions so that learning objectives can be achieved optimally.

\section{CONCLUSION}

Based on the results of data analysis, the instrument obtained very high validity and reliability. The learning outcomes instruments for the fourth-grade elementary school students have met the valid and reliable criteria. So it can be said that the instrument for assessing learning outcomes in mathematics for fourth-grade elementary school students is valid and feasible to be used as an assessment instrument for students.

\section{REFERENCES}

Abdul Karim, Dini Savitri, \& Hasbullah. (2020). Pengembangan Media Pembelajaran Matematika Berbasis Android Di Kelas 4 Sekolah Dasar. Jurnal Lebesgue: Jurnal Ilmiah Pendidikan Matematika, Matematika Dan Statistika, 1(2), 63-75. https://doi.org/10.46306/lb.v1i2.17.

Adjii, K. (2019). Instrumen penilaian kedisiplinan siswa sekolah menengah kejuruan. Assessment and Research on Education, 1(1). https://doi.org/10.33292/arisen.v1i1.19.

Agung, A. Ag. gede. (2011). Prosedur Penelitian Suatu Pendekatan Praktek. Universitas Pendidikan Ganesha.

Anwar, Y., Selamet, A., Huzaifah, S., \& Madang, K. (2020). Training in developing higher-order thinking based online test instrument for biology teachers in Sekayu City. Journal of Community Service and Empowerment, 1(3), 150-155. https://doi.org/10.22219/jcse.v1i3.12241.

Ardhiyah, M. A., \& Radia, E. H. (2020). Pengembangan Media Berbasis Adobe Flash Materi Pecahan Matematika untuk Meningkatkan Hasil Belajar. Jurnal Penelitian Dan Pengembangan Pendidikan, 4(3), 479-485. https://doi.org/10.23887/jppp.v4i3.28258.

Ariani, T. (2020). Analysis of Students' Critical Thinking Skills in Physics Problems. Physics Educational Journal, 3(1), 1-13. https: //doi.org/10.37891/kpej.v3i1.119.

Arif, M. (2016). Pengembangan Instrumen Penilaian Mapel Sains melalui Pendekatan Keterampilan Proses Sains SD/MI. Ta'allum: Jurnal Pendidikan Islam, 4(1). https://doi.org/10.21274/taalum.2016.4.1.123-148. 
Asghar, A., Jamil, I., Iqbal, A., \& Yasmin, M. (2018). Learner Attitude towards EFL Learning: A Response from Art and Design. Open Journal of Social Sciences, 06(05), 81-88. https: //doi.org/10.4236/jss.2018.65007.

Bayles, J., Peterson, A. D., Pitts, S. J., Bian, H., Burkholder, S., Hegde, A. V., \& Stage, V. C. (2021). Food-Based Science, Technology, Engineering, Arts, and Mathematics (STEAM) Learning Activities May Reduce Decline in Preschoolers' Skin Carotenoid Status. Journal of Nutrition Education and Behavior, 53(4). https://doi.org/10.1016/j.jneb.2020.10.017.

Bosica, J., S.Pyper, J., \& MacGregor, S. (2021). Incorporating problem-based learning in a secondary school mathematics preservice teacher education course. Teaching and Teacher Education, 102, 103335. https: //doi.org/10.1016/j.tate.2021.103335.

Chan, S. W., \& Ismail, Z. (2014). Developing Statistical Reasoning Assessment Instrument for High School Students in Descriptive Statistics. Procedia - Social and Behavioral Sciences, 116. https://doi.org/10.1016/j.sbspro.2014.01.943.

Crismono, P. C. (2017). Pengaruh Outdoor Learning Terhadap Kemampuan Berpikir Kritis Matematis Siswa The Influence Of Outdoor Learning On The Mathematical Critical Thinking Skills Of Students. Junal Pendidikan Matematika Dan Sains, 4(2), 106-113. https: //doi.org/10.21831/jpms.v5i2.15482.

Davidi, E. I. N., Sennen, E., \& Supardi, K. (2021). Integrasi Pendekatan STEM (Science, Technology, Enggeenering and Mathematic) Untuk Peningkatan Keterampilan Berpikir Kritis Siswa Sekolah Dasar. Scholaria: Jurnal Pendidikan Dan Kebudayaan, 11(1), 11-22. https://doi.org/10.24246/j.js.2021.v11.i1.p11-22.

Dessiane, S. T., \& Kristin, F. (2021). Pengembangan Instrumen Penilaian Sikap Sosialpembelajaran Tematik Kelas 4 SD. Jurnal Pendidikan Ilmu Pengetahuan Sosial Indonesia, 6(1), 21-26. https://doi.org/10.26737/jpipsi.v6i1.2310.

Durán, C. A., M.Córdova, F., \& Palominos, F. (2019). A conceptual model for a cyber-social-technologicalcognitive smart medium-size port. Procedia Computer Science, 162, 94-101. https://doi.org/10.1016/j.procs.2019.11.263.

Dwipayana, I. K. A. A., Parmiti, D. P., \& Diputra, K. S. (2018). Pengaruh Pendekatan Pendidikan Matematika Realistik Berbasis Open Ended Terhadap Kemampuan Berpikir Kreatif Siswa SD KELAS V. Journal of Education Technology Universitas Pendidikan Ganesha, 2(3), 87-94. https://doi.org/10.23887/jet.v2i3.16380.

Faidah, N., Masykur, R., Andriani, S., \& Lina Herlina. (2019). Realistic Mathematics Education ( Rme ) Sebagai Sebuah Pendekatan Pada Pengembangan Modul Matematika Berbasis Teori Multiple Intelligences Realistic Mathematics Education ( Rme ) As an Approach To Development of Mathematical Module Based on Multiple Intel. Indonesia Journal of Science and Mathematics Education, 02(3), 328-332. https://doi.org/10.24042/ijsme.v2i3.4396.

Febriana, R., Yusri, R., \& Delyana, H. (2020). Modul Geometri Ruang Berbasis Problem Based Learning Terhadap Kreativitas Pemecahan Masalah. AKSIOMA: Jurnal Program Studi Pendidikan Matematika, 9(1), 93. https://doi.org/10.24127/ajpm.v9i1.2591.

Febriyanti, N. P. D., \& Jayanta, I. N. L. (2018). Pengaruh Model Pembelajaran Cooperative Script Berbantuan Penilaian Portofolio terhadap Hasil Belajar PKn. Mimbar PGSD Undiksha, 6(2), 137144. https://doi.org/10.23887/jjpgsd.v6i2.19468.

Friantary, H., \& Martina, F. (2018). Evaluasi Implementasi Penilaian Hasil Belajar Berdasarkan Kurikulum 2013 oleh Guru Bahasa Inggris dan Bahasa Indonesia di MTS Ja-Alhaq Kota Bengkulu. Silampari Bisa: Jurnal Penelitian Pendidikan Bahasa Indonesia, Daerah, Dan Asing, 1(2), 76-95. https://doi.org/10.31540/silamparibisa.v1i2.202.

Gaol, P. L., Khumaedi, M., \& Masrukan, M. (2017). Pengembangan Instrumen Penilaian Karakter Percaya Diri pada Mata Pelajaran Matematika Sekolah Menengah Pertama. Journal of Research and Educational Research Evaluation,

$6(1)$. https://journal.unnes.ac.id/sju/index.php/jere/article/view/16209.

Gunawan, I., \& Palupi, A. R. (2012). Taksonomi Bloom - Revisi Ranah Kognitif: Kerangka Landasan Untuk Pembelajaran, Pengajaran, Dan Penilaian. Premiere Educandum: Jurnal Pendidikan Dasar Dan Pembelajaran, 2(2). https://doi.org/10.25273/pe.v2i02.50.

Indriani, A. (2018). Penggunaan Blok Pecahan pada Materi Pecahan Sekolah Dasar. Jurnal Ilmiah Pendidikan Matematika, 3(1), 11-16. https://doi.org/10.26877/jipmat.v3i1.2418.

Jannah et al. (2021). Efektivitas Penggunaan E-Modul Terhadap Hasil Belajar Kognitif Pada Materi Sistem Pencernaan Manusia di Madrasah Tsanawiyah. Jurnal Basicedu, 5(2), 1060-1066. https: //doi.org/10.31004/basicedu.v5i3.952.

Kim, S.-H., \& Sihyun Park. (2021). Influence of Learning Flow and Distance E-Learning Satisfaction on 
Learning Outcomes and the Moderated Mediation Effect of Social-Evaluative Anxiety in Nursing College Students during the COVID-19 Pandemic: A Cross-Sectional Study. Nurse Education in Practice, 6(103197). https://doi.org/10.1016/j.nepr.2021.103197.

Kirom, A. (2017). Peran Guru Dan Peserta Didik Dalam Proses Pembelajaran Berbasis Multikultural. Al Murabbi, 3(1), 69-80. https://jurnal.yudharta.ac.id/v2/index.php/pai/article/view/893.

Lwande, C., Muchemi, L., \& Oboko, R. (2021). Identifying learning styles and cognitive traits in a learning management system. Heliyon, 7(8). https://doi.org/10.1016/j.heliyon.2021.e07701.

Maghfiroh, Y., \& Hardini, A. T. A. (2021). Pengembangan Modul Pembelajaran Matematika Materi Pecahan Kelas V Sekolah Dasar. Jurnal Educatio FKIP UNMA, 7(2), 272-281. https: //doi.org/10.31949/educatio.v7i2.997.

Maqableh, M., \& Alia, M. (2021). Evaluation online learning of undergraduate students under lockdown amidst COVID-19 Pandemic: The online learning experience and students' satisfaction. Children and Youth Services Review, 128, 106160. https://doi.org/10.1016/j.childyouth.2021.106160.

Miranda, J., Navarrete, C., Noguez, J., Molina-Espinosa, J.-M., Ramírez-Montoya, M.-S., Navarro-Tuch, S. A., Close, \& Bustamante-Bello, M.-R. (2021). The core components of education 4.0 in higher education: Three case studies in engineering education. Computers \& Electrical Engineering, 93. https://doi.org/https://doi.org/10.1016/j.compeleceng.2021.107278.

Monica, Gorghiu, Bîzoi, \& Marra. (2011). a Modern Instrument Used in Teachers ' Training Process. Procedia Computer Science, 3(1), 563-567. https://doi.org/10.1016/j.procs.2010.12.09.

Ndiung, S., \& Jediut, M. (2020). Pengembangan instrumen tes hasil belajar matematika peserta didik sekolah dasar berorientasi pada berpikir tingkat tinggi. Premiere Educandum : Jurnal Pendidikan Dasar Dan Pembelajaran, 10(1), 94. https://doi.org/10.25273/pe.v10i1.6274.

Netriwati. (2018). Penerapan Taksonomi Bloom Revisi untuk Meningkatkan Kemampuan Pemahaman Konsep Matematis. Desimal: Jurnal Matematika, https://doi.org/https://doi.org/10.24042/djm.v1i3.3238.

Nugraheni, E. A. (2013). Pengaruh Pendekatan PMRI terhadap Aktivitas dan Pemahaman Konsep Matematika Siswa SMP. Pythagoras: Jurnal Pendidikan Matematika, 8(1), 101-108. https: //doi.org/10.21831/pg.v8i1.8498.

Pantiwati, Y. (2016). Hakekat Asesmen Autentik Dan Penerapannya Dalam Pembelajaran Biologi. Jurnal Edukasi Matematika Dan Sains, 1(1), 18. https://doi.org/10.25273/jems.v1i1.773.

Pentury, H., Festiyed, Hamdi, \& Yurnetti. (2019). Pembuatan Lembar Kerja Peserta Didik (LKPD) Berbasis Model Discovery Learning Pada Materi Gelombang Berbantuan Aplikasi Android Untuk Kelas XI SMA/MA. Pillar of Physics Education, 12(4), 617-624. https://doi.org/10.24036/7144171074.

Prastikawati, E. F., Wiyaka, W., \& Budiman, T. C. S. (2021). Pelatihan Penyusunan Soal Bahasa Inggris Berbasis HOTS bagi Guru Bahasa Inggris SMP. Jurnal Pengabdian Masyarakat, 6(1). https: //doi.org/10.30653/002.202161.761.

Sari, A. N., Wahyuni, R., \& Rosmaiyadi, R. (2016). Penerapan Pendekatan Open-Ended untuk Meningkatkan Kemampuan Berpikir Kritis Siswa Pada Materi Aljabar Kelas VIII SMP Negeri 10 Pemangkat. JPMI (Jurnal Pendidikan Matematika Indonesia), 1(1), 20. https://doi.org/10.26737/jpmi.v1i1.78.

Sari, F. K., Rakimahwati, R., \& Fitria, Y. (2019). Hubungan Minat dengan Hasil Belajar Peserta Didik Pada Pelajaran Matematika Kelas VI SDN 25 Jati Tanah Tinggi. Journal of Elementary Education, 3(2). https://doi.org/10.31004/basicedu.v3i2.18.

Sari, K. M., \& Setiawan, H. (2020). Kompetensi Pedagogik Guru dalam Melaksanakan Penilaian Pembelajaran Anak Usia Dini. Jurnal Obsesi: Jurnal Pendidikan Anak Usia Dini, 4(2). https://doi.org/https://doi.org/10.31004/obsesi.v4i2.478.

Schlimbach, R., \& Asghari, R. (2020). Das Digital Canvas: Ein Instrument zur Konzeption digitaler Geschäftsmodelle. HMD Praxis Der Wirtschaftsinformatik, 57(4), 866-878. https://doi.org/10.1365/s40702-020-00624-9.

Segers, M., Martens, R., \& Bossche, P. Van den. (2018). Understanding how a case-based assessment instrument influences student teachers' learning approaches. Teaching and Teacher Education, 24(7). https://doi.org/10.1016/j.tate.2008.02.022.

Setiawan, D. (2017). Pendekatan Saintifik dan Penilaian Auntentik untuk Meningkatkan Mutu Pembelajaran Pendidikan Agama Islam. AL-ASASIYYA: Journal Of Basic Education, 1(2). https: //doi.org/10.24269/ajbe.v1i2.683.

Soekisno, R. B. A. (2015). Pembelajaran Berbasis Masalah Untuk Meningkatkan Kemampuan Argumentasi Matematis Mahasiswa. Infinity Journal, 4(2), 120. https://doi.org/10.22460/infinity.v4i2.77.

Solihah, A. N., Jubaedah, Y., \& Rifa'i, M. S. S. (2020). Pengembangan Instrumen Pengukuran Perkembangan Sosial-Emosional Anak Berbasis Home-Based Childcare. Widyadari, 6(1). https://doi.org/10.5281/zenodo.3517997. 
Srirahayu, R. R. Y., \& Arty, I. S. (2018). Validitas dan reliabilitas instrumen asesmen kinerja literasi sains pelajaran Fisika berbasis STEM. Jurnal Penelitian Dan Evaluasi Pendidikan, 22(2), 168-181. https: //doi.org/10.21831/pep.v22i2.20270.

Subagia, I. W., \& Wiratma, I. G. L. (2016). Profil Penilaian Hasil Belajar Siswa Berdasarkan Kurikulum 2013. JPI (Jurnal Pendidikan Indonesia), 5(1), 39-54. https: //doi.org/10.23887/jpi-undiksha.v5i1.8293.

Trisnawati, D. F., \& Suharno, S dan Kamsiyati, S. (2019). Efektivitas Media Realia dan Blok Pecahan Terhadap Kemampuan Berhitung Materi Pecahan Peserta Didik Sekolah Dasar. Jurnal Pendidikan Dasar, 7(1), 46-50. https://doi.org/10.20961/jpd.v7i1.29316.

Umami, R., Rusdi, M., \& Kamid, K. (2021). Pengembangan Instrumen Tes Untuk Mengukur Higher Order Thinking Skills (Hots) Berorientasi Programme For International Student Asessment (Pisa) Pada Peserta Didik. JP3M: Jurnal Penelitian Pendidikan Dan Pengajaran Matematika, 7(1). https://doi.org/10.37058/jp3m.v7i1.2069.

Utami, D. A. P., \& Wardani, N. S. (2020). Pengembangan Instrumen Penilaian Kognitif dalam Pembelajaran Tematik Kelas 5 SD. Jurnal Ilmiah Kependidikan, 20(2), 1-18. https: //doi.org/10.12345/lentera.v12i2.463.

Wicaksono, P. N., Kusuma, I. J., Festiawan, R., Widanita, N., \& Anggraeni, D. (2020). Evaluasi penerapan pendekatan saintifik pada pembelajaran pendidikan jasmani materi teknik dasar passing sepak bola. Jurnal Pendidikan Jasmani Indonesia, 16(1), 41-54. https: //doi.org/10.21831/jpji.v16i1.29774.

Wicaksono, T. P., Muhardjito, \& Harsiati, T. (2016). Pengembangan penilaian sikap dengan teknik observasi, self assessment, dan peer assessment pada pembelajaran tematik kelas V SDN Arjowinangun 02 Malang. Jurnal Pendidikan: Teori, Penelitian, Dan Pengembangan, 1(1), 45-51. https://doi.org/http://dx.doi.org/10.17977/jp.v1i2.5214.

Widodo, A. (2020). Nilai Budaya Ritual Perang Topat Sebagai Sumber Pembelajaran IPS Berbasis Kearifan Lokal di Sekolah Dasar. Gulawentah:Jurnal Studi Sosial, 5(1), 1. https://doi.org/10.25273/gulawentah.v5i1.6359.

Wulandari, L., Widodo, J., \& Sulhadi. (2019). The Implementation of Learning Instrument of Soil Forming Material with Cooperative Model Type of Team Assisted Individualization of Elementary School $\begin{array}{llll}\text { Students. Journal of Primary } & \text { Education, } & 9(1),\end{array}$ https://journal.unnes.ac.id/sju/index.php/jpe/article/view/29219.

Wulandari, Sudatha, \& Simamora. (2020). Pengembangan Pembelajaran Blended Pada Mata Kuliah Ahara Yoga Semester II di IHDN Denpasar. Jurnal Edutech Undiksha, 8(1), 1-15. https: //doi.org/10.23887/jeu.v8i1.26459.

Yusuf, M. (2017). Asesmen dan Evaluasi Pendidikan. Kencana.

Yusup, F. (2018). Uji Validitas dan Reliabilitas Instrumen Penelitian Kuantitatif. Jurnal Tarbiyah : Jurnal Ilmiah Kependidikan, 7(1), 17-23. https://doi.org/10.18592/tarbiyah.v7i1.2100.

Zuliani, D., Florentinus, T. S., \& Ridlo, S. (2017). Pengembangan Instrumen Penilaian Karakter pada Siswa Kelas IV Sekolah Dasar. Journal of Research and Educational Research Evaluation, 6(1). https: //journal.unnes.ac.id/sju/index.php/jere/article/view/16207. 